\title{
Caracteristici epidemiologice principale ale cazurilor de COVID-19 internate în spital din prima linie de apărare din Bucureşti, România
}

\author{
Niculae Ion Nedelcu', Radu Robert Mateescu', Emanoil Ceauşu ${ }^{1,3,4}$, \\ Petre lacob Calistru², Simin-Aysel Florescu ${ }^{1,3}$ \\ ${ }^{1}$ Spitalul de Boli Infecţioase şi Tropicale „Dr. Victor Babeş“, Bucureşti, România \\ 2Fundaţia Spital General „Dr. Victor Babeş“,Bucureşti, România \\ 3Universitatea de Medicină şi Farmacie „Carol Davila“, Bucureşti, România \\ ${ }^{4}$ Academia de Ştiinţe Medicale din România
}

\begin{abstract}
REZUMAT
În acest studiu retrospectiv, unicentru, am dorit să reliefăm caracteristicile cheie ale primelor 100 de cazuri de COVID-19 spitalizate în clinica noastră după desemnarea acesteia drept unitate din linia întâi pentru spitalizarea acestora. Astfel, vârsta medie a cazurilor a fost de 44,7 ani (SD: 15,9 ani), iar prevalenţa genului feminin a fost de $57,4 \%$. Pe grupe de vârstă, prevalenţa pacienţilor în vârstă de $<20$ de ani $(7,8 \%)$ a fost semnificativ $(p<0,05)$ mai mică decât prevalenţa pacienţilor din grupa de vârstă $20-64$ de ani $(77,2 \%)$. Cea mai frecventă ocupaţie $(31,7 \%)$ a fost cea de lucrător sanitar. Cel mai frecvent mod de expunere la sursa de infecţie a fost reprezentat de contactul cu unităţi sanitare $(44,6 \%)$, urmat de contactul cu un caz de COVID-19 confirmat sau suspect $(30,7 \%)$ şi apoi de călătorie internaţională recentă $(18,8 \%)$. La $30 \%$ dintre cazuri în care s-a consemnat prezenţa cel puţin a unei comorbidităţi recente, boala cardiovasculară incluzând hipertensiunea arterială a fost cel mai frecvent consemnată comorbiditate $(13,9 \%)$. În ceea ce priveşte severitatea, este de notat faptul că 6 pacienţi au decedat în primele 14 zile de la internare; toate fatalităţile au survenit la persoane în vârstă şi $89,3 \%$ dintre aceştia aveau boli cronice de rinichi. Datele reliefate în această lucrare pot ajuta la un management mai bun al pandemiei COVID-19.
\end{abstract}

Cuvinte cheie: COVID-19, SARS-CoV-2, spital din prima linie, internare, epidemiologie

\section{INTRODUCERE}

Pe 30 ianuarie 2020, Organizaţia Mondială a Sănătăţii (OMS) a declarat epidemia provocată de noul coronavirus (2019-nCoV) drept urgenţă de sănătate publică la nivel internaţional (1). Pe 11 martie 2020, OMS-ul a caracterizat COVID-19 drept pandemie (2). Acestea au survenit după ce, în ultima zi a anului 2019, autorităţile chineze au anunţat oficial ca sunt implicate în managementul unei epidemii de pneumonie de cauză necunoscută. Pe data de 7 ianuarie 2020, s-a raportat că pneumonia idiopatică a fost cauzată de un nou coronavirus şi că informaţiile privind agentul patogen au fost puse la dispoziţia cercetătorilor din întreaga lume (3). OMS a denumit noul virus drept noul coronavirus din anul 2019 (2019-nCoV). Întrucât caracteristicile epidemiologice ale noii maladii sunt necunoscute, acestea sunt investigate prin comparare cu sindroame clinice similare precum Severe Acute Respiratory Syndrome (SARS) şi, respectiv, Middle East Respiratory Syndrome (MERS). Investigarea rapidă şi determinarea caracteristicilor epidemiologice ale noii maladii infecţioase sunt cruciale pentru limitarea transmiterii şi realizarea unor evoluţii favorabile prin diagnostic şi management precoce. 
Distribuirea de date cruciale între epidemiologii din toată lumea este critică şi poate sprijini la cunoaşterea caracteristicilor acestei noi infecţii şi prevenirea, în consecinţă, a răspândirii acesteia.

Similar cu lucrările altor autori, bazate pe cercetarea la începutul unei epidemii a unui eşantion redus de cazuri $(3,4)$, această lucrare este o evaluare de risc la primele 100 de cazuri de pacienţi COVID-19 internaţi în clinica noastră de boli infecţioase şi tropicale, cazuri la care sursa de infecţie, mecanismul de transmitere şi gazda susceptibilă au fost clar depistate, făcând posibilă generarea de incidenţe, prevalenţe, intervale de confidenţă $95 \%$, precum şi coeficienţi de tendinţă. Aceşti parametri care sunt mai lesne de calculat în faza precedentă transmiterii comunitare a agentului patogen, cum este cazul nostru, sunt necesari celor care conduc politica sanitară să facă estimări de logistică şi să ia decizii de control înalt eficiente (inclusiv cele neprietenoase pentru populaţie), în concordanţă cu realitatea din teren şi evitând astfel improvizaţia şi liberul arbitru.

\section{OBIECTIV}

Obiectivul acestui studiu a fost reliefarea principalelor caracteristici epidemiologice ale cazurilor de COVID-19 internate în clinica noastră, din prima linie de apărare, în vederea furnizării de noţiuni de bază necesare controlului pandemiei.

\section{METODE}

\section{Setul de date}

În Bucureşti, evoluţia temporală a pandemiei COVID-19 a implicat apariţia în prima etapă de cazuri de import, urmată de o a doua etapă, dominată de cazuri transmise local, având sursa de infecţie uşor de recunoscut (spre exemplu, o unitate sanitară sau o persoană cu infecţie confirmată sau suspectă) şi, în fine, a treia etapă, definită drept etapa de transmitere comunitară, dominată de cazuri la care sunt imposibil de asociat o sursă şi un mecanism de transmitere al infecţiei. Eşantionul nostru include cazurile de COVID-19 aparţinând celor două etape de început ale pandemiei, cazuri internate în clinica noastră în perioada 3-24 martie 2020.

\section{Sursa datelor}

Toate datele au fost extrase din formularul de supraveghere a cazului (5), care reprezintă documentul legal destinat vehiculării informaţiilor socio-demografice, clinice şi epidemiologice ale fiecărui caz de COVID-19 de la nivelul operaţional şi până la nivelul decizional.

\section{Definiția cazului}

Un caz confirmat de COVID-19 este reprezentat de un rezident din municipiul Bucuresti, cu cel putin un rezultat pozitiv la testul RT-PCR (real-time reversetranscription-polymerase-chain-reaction) sau o secvenţă genetică care se potriveşte cu 2019-nCoV (6).

\section{Profil temporal}

Curba epidemică a cazurilor a fost generată prin alocarea cazurilor după rangul săptămânii calendaristice a zilei în care a avut loc internarea în spital (spre exemplu, un caz internat în spital pe data de 12 martie a fost alocat în săptămâna a 11-a). Tendinţa numărului săpămânal de cazuri a fost estimată prin regresie lineară.

\section{Managementul cazurilor}

O bază de date EpiInfo (7) de concepţie proprie a fost alimentată cu conţinutul formularului de investigare a cazului şi apoi interogată în funcţie de nevoi - o valoare mai mică decat 0,05 a fost desemnat drept semnificaţie statistică.

\section{Eșantionaj}

$\mathrm{Nu}$ a fost necesar, întrucât toate cazurile care au corespuns criteriilor de includere au fost alocate în setul de date de studiu.

\section{Aprobarea comitetului de bioetică}

Colectarea de date privind cazurile a fost desemnată de către autoritatea naţională de sănătate publică ca făcând parte din investigarea epidemiei, motiv pentru care a fost exceptată de la aprobarea comitetului de bioetică al spitalului.

\section{REZULTATE}

101 cazuri de COVID-19 au întrunit criteriile de includere; vârsta medie a cazurilor a fost de 44,7 ani (SD: 15,9 ani) (IQR: 36-53 ani). Pe grupe de vârstă, 58 dintre pacienţi erau femei şi, respectiv, 43 erau bărbaţi (Tabel 1); incidenţa cazurilor după gen a fost similară: (5,10 vs. 4,31) [(risc relativ (RR): 1,18; 95\% interval de confidenţă (IC): $(0,80-1,71) ; \chi 2: 0,70$; valoare p: 0,4031)] 
TABEL 1. Prevalenţa şi incidenţa cazurilor COVID-19 internate după gen

\begin{tabular}{|l|c|c|}
\hline Gen & $\begin{array}{c}\text { Nr. (\%) } \\
\text { (95\% limite de confidenţă) }\end{array}$ & $\begin{array}{c}\text { Incidenţă } \\
\text { (cazuri/105 locuitori) }\end{array}$ \\
\hline Feminin & $58(57,4 \%)(47,2 \%-67,2 \%)$ & 5,10 \\
\hline Masculin & $43(42,6 \%)(32,8 \%-52,8 \%)$ & 4,31 \\
\hline Total & $101(100,0 \%)$ & 4,74 \\
\hline
\end{tabular}

Pe grupe de vârstă, cel mai prevalent a fost grupul „Adult"“ (77,2\%) (Tabel 2); cea mai mare incidenţă a fost, de asemenea, calculată în grupul de vârstă "Adult". Incidenţa cazurilor din grupul „Adult" a fost statistic semnificativ mai mare decât în grupul „Junior" (5,59 vs. 2,17) [RR: 2,57; 95\% IC: $(1,24-5,31)$; ఒ2: 6,94; p: 0,0084)], dar a fost similară cu incidenţa cazurilor din grupul „Senior“ [RR: 1,38; 95\% IC: $(0,79-2,40) ; \chi 2: 1,32 ; \mathrm{p}: 0,2512)]$.

TABEL 2. Prevalenţa şi incidenţa cazurilor COVID-19 internate în funcţie de grupa de vârstă

\begin{tabular}{|l|c|c|}
\hline $\begin{array}{l}\text { Grupe de } \\
\text { vârstă (ani) şi } \\
\text { codificări }\end{array}$ & $\begin{array}{c}\text { Număr (\%) cazuri şi 95\% } \\
\text { limite de confidenţă }\end{array}$ & $\begin{array}{c}\text { Incidenţă } \\
\text { (cazuri/105 } \\
\text { locuitori) }\end{array}$ \\
\hline Junior (0-19) & $8(7,9 \%)(3,5 \%-15,0 \%)$ & 2,17 \\
\hline Adult (20-64) & $78(77,2 \%)(67,8 \%-85,0 \%)$ & 5,59 \\
\hline Senior (65+) & $15(14,9 \%)(8,6 \%-23,3 \%)$ & 4,05 \\
\hline Total & $101(100,0 \%)$ & 4,74 \\
\hline
\end{tabular}

\section{Expunere}

Prevalenţa cazurilor după natura expunerii la sursa de infecţie s-a distribuit între 5,9\% în cazul expunerii în comunitate şi până la 44,6\% în cazul expunerii în unitate sanitară (Tabel 3).

TABEL 3. Prevalenţa (\%) cazurilor după natura expunerii sortare în ordine descendentă

\begin{tabular}{|l|c|c|}
\hline $\begin{array}{l}\text { Circumstanţe ale expunerii n } \\
\text { perioada de } 14 \text { zile precedentă } \\
\text { internării în spital -*) }\end{array}$ & $\begin{array}{c}\text { Nr. (procent } \\
\text { din total) }\end{array}$ & $\begin{array}{c}\mathbf{9 5 \%} \text { limite de } \\
\text { confidenţă }\end{array}$ \\
\hline Vizită în unitate sanitară & $45(44,6 \%)$ & $36,7 \%-54,8 \%$ \\
\hline $\begin{array}{l}\text { Contact respirator cu caz } \\
\text { con t业uspect }\end{array}$ & $31(30,7 \%)$ & $21,9 \%-40,7 \%$ \\
\hline $\begin{array}{l}\text { Venit din călătorie } \\
\text { internaţională }\end{array}$ & $19(18,8 \%)$ & $11,7 \%-27,8 \%$ \\
\hline $\begin{array}{l}\text { Niciuna dintre cele de mai sus } \\
\text { (comunitară) }\end{array}$ & $6(5,9 \%)$ & $(2,2 \%-12,5 \%)$ \\
\hline Total & $\begin{array}{c}101 \\
(100,0 \%)\end{array}$ & - \\
\hline
\end{tabular}

*) S-a selectat cea mai plauzibilă expunere cand au fost raportate expuneri multiple

Prevalenţa expunerii în funcţie de gen a fost asemănătoare $[\chi 2: 5,05$; grade de libertate $(\mathrm{GL}): 3$; p: 0,1676], dar prevalenţele expunerii cazurilor în funcţie de grupa de vârstă au diferit semnificativ $[\chi 2$ : 13,63; GL: 6; p: 0,0340]. Astfel, cea mai prevalentă expunere la grupul „Junior“ (50\%) a fost prin contact respirator cu un caz confirmat/suspect, pe când cea mai frecventă expunere a grupului „Adult“ $(47,4 \%)$ sau la grupul „Senior“ (46,7\%) s-a consumat prin vizita la o unitate sanitară (tabele neprezentate aici).

\section{Ocupație}

Cea mai frecventă ocupaţie $(31,7 \%)$ a fost cea de lucrător sanitar (Tabel 4).

TABEL 4. Prevalenţa cazurilor în funcţie de ocupaţie sortare în ordine descendentă cu excepţia categoriei „Alte ocupaţii“

\begin{tabular}{|l|c|c|}
\hline Ocupaţie & $\begin{array}{c}\text { Nr. (procent } \\
\text { din total) }\end{array}$ & $\begin{array}{c}\mathbf{9 5 \%} \\
\text { limite de } \\
\text { confidenţă }\end{array}$ \\
\hline Lucrător sanitar & $32(31,7 \%)$ & $22,8 \%-41,7 \%$ \\
\hline Pensionar & $14(13,9 \%)$ & $7,8 \%-22,2 \%$ \\
\hline Lucrător în servicii publice & $9(8,9 \%)$ & $4,2 \%-16,2 \%$ \\
\hline Fără ocupaţie & $7(6,9 \%)$ & $2,8 \%-13,8 \%$ \\
\hline Elev/student (vârsta: 6-24 ani) & $7(6,9 \%)$ & $2,8 \%-13,8 \%$ \\
\hline $\begin{array}{l}\text { Copil preşcolar (vârsta: sub 6 } \\
\text { ani) }\end{array}$ & $3(3,0 \%)$ & $0,6 \%-8,4 \%$ \\
\hline Alte ocupaţii & $29(28,7 \%)$ & $20,1 \%-38,6 \%$ \\
\hline Total & $101(100,0 \%)$ & - \\
\hline
\end{tabular}

\section{Precondiții medicale}

Niciuna dintre precondiţiile medicale listate în formularul de supraveghere nu s-a găsit la 70 dintre cazurile noastre $(69,9 \%)$; la restul cazurilor, cea mai frecventă precondiţie medicală recentă $(13,9 \%)$ a fost boala cardiovasculară cronică, inclusiv hipertensiunea arterială (Tabel 5).

TABEL 5. Prevalenţa cazurilor după tipul precondiţiei medicale asociate - sortare în ordine descendentă cu excepţia categoriei „Fără“

\begin{tabular}{|l|c|c|}
\hline Precondiţii medicale* & $\begin{array}{c}\text { Nr. (procent din } \\
\text { total) }\end{array}$ & $\begin{array}{c}\text { 95\% limite de } \\
\text { confidenţă }\end{array}$ \\
\hline $\begin{array}{l}\text { Boală cardiovasculară } \\
\text { cronică inclusiv HTA }\end{array}$ & $14(13,9 \%)$ & $7,8 \%-22,2 \%$ \\
\hline $\begin{array}{l}\text { Dezordini oncologice/ } \\
\text { hematologice cronice }\end{array}$ & $5(5,0 \%)$ & $1,6 \%-11,2 \%$ \\
\hline $\begin{array}{l}\text { Boală renală cronică inclusiv } \\
\text { sub dializă }\end{array}$ & $5(5,0 \%)$ & $1,6 \%-11,2 \%$ \\
\hline Boală hepa ă tronică & $2(2,0 \%)$ & $0,2 \%-7,0 \%$ \\
\hline tmă inclusiv HIV & $2(2,0 \%)$ & $0,2 \%-7,0 \%$ \\
\hline Diabe & $1(1,0 \%)$ & $0,0 \%-5,4 \%$ \\
\hline $\begin{array}{l}\text { Boală pulmonară cronică } \\
\text { inclusiv BPOC }\end{array}$ & $1(1,0) \%)$ & $0,0 \%-5,4 \%$ \\
\hline Sarcină & $1(1,0 \%)$ & $0,0 \%-5,4 \%$ \\
\hline Fără & $70(69,9 \%)$ & $59,3 \% 78,1 \%$ \\
\hline Total & $101(100,0 \%)$ & - \\
\hline
\end{tabular}

*) S-a selectat precondiția considerată mai severă în cazul în care mai multe precondiții au fost raportate la un subiect. 


\section{Semne și simptome}

Ca urmare a naturii definiţiei de caz, bazată numai pe rezultatul de laborator, noi am exclus analiza de semne şi simptome descrise la internarea în spital.

\section{Severitate}

6 pacienţi din seria analizată de noi au decedat în primele 14 zile după internarea în spital, aceştia având următoarele trăsături:

- Rata de fatalitate a cazurilor (CFR): 5,9\% (95\% IC: $2,2 \%-12,5 \%$ );

- 83,3\% dintre fatalităţi au intervenit la pacienţi cu boală renală cronică necesitând dializă;

- Toate cazurile fatale au aparţinut grupei de vârstă "Senior";

- Genul a fost distribuit egal între decese.

\section{Profil temporal}

Pe parcursul primelor 3 săptămâni consecutive, frecvenţa cazurilor de COVID-19 internate în clinica noastră a crescut de la 4 cazuri în săptămâna a 10-a până la 76 de cazuri în săptămâna a 12-a, cea mai recentă săptămână completă (tabel 6). Rezultatul regresiei lineare a frecvenţei săptămânale a cazurilor a fost următorul: coeficient de corelaţie (r2): 1,00; coeficient de regresie $(\beta)$ : 36 de cazuri; $p: 0,0000$.

TABEL 6. Frecvenţa cazurilor noi raportată pe săptămâni

\begin{tabular}{|c|c|}
\hline $\begin{array}{c}\text { Rangul săptămânii } \\
\text { (ultima zi duminica) }\end{array}$ & Nr. de internări în spital \\
\hline $10^{\text {th }}(08 / 03)$ & 4 \\
\hline $11^{\text {th }}(15 / 03)$ & 41 \\
\hline $12^{\text {th }}(22 / 03)$ & 76 \\
\hline $13^{\text {th }}(29 / 03)^{*}$ & 17 \\
\hline
\end{tabular}

*) incompletă - doar până pe 24 martie

\section{DISCUŢII}

\section{Vârstă și gen}

În setul nostru de date, am găsit o vârstă medie de 44,7 ani şi o frecvenţă de 58 de bărbaţi şi 43 de femei. Prin contrast, la începutul epidemiei de COVID-19 din China, cercetătorii locali au descris o vârstă medie de 55,5 ani, cu o frecvenţă de 67 bărbaţi şi, respectiv, 32 de femei $(4,8)$. Noi speculăm că vârsta mai înaintată a pacienţilor din China ar putea explica fatalitatea mai înaltă din această ţară. În plus, subliniem prezenţa scăzută $(7,8 \%)$ a copiilor şi adolescenţilor în setul nostru de date.

\section{Ocupația}

Cel mai tulburător rezultat al analizei noastre a fost prevalenţa neaşteptat de mare $(31,7 \%)$ a lucrătorilor sanitari în lista de ocupaţii. Noi credem că acest aspect se datorează efectului de "superspreading", un fenomen raportat frecvent la începutul unei epidemii $(9,10)$. Totuşi, dorim să subliniem că durata îndelungată de muncă şi igiena suboptimală a mâinilor au fost factori de risc validaţi în rândul lucrătorilor sanitari (11).

\section{Rata de fatalitate a cazurilor}

Valoarea găsită în acest raport este mai mare decât cea iterată într-un raport din China (12). Totuşi, trebuie notat că numărul total de cazuri COVID-19 (adică numitorul fracţiei de calcul a ratei) este plauzibil să fie mai mare ca urmare a dificultăţilor inerente de identificare şi numărare a cazurilor clinic uşoare şi asimptomatice.

\section{Profilul temporal}

Ca urmare a efectului de "superspread" noi ne-am abţinut să estimăm numărul reproductiv (Ro), aşa cum au făcut alţi autori (13). În schimb, prin regresie lineară, am explorat tendinţa evoluţiei numărului de cazuri, ceea ce a confirmat observaţia noastră empirică, că în primele 3 săptămâni consecutive ale pandemiei a existat o creştere consistentă a numărului de cazuri pe săptămână (r2: > 95\%), iar rata prognozată de creştere săptămânală a fost de 30,5 cazuri.

\section{CONCLUZII}

Prin acest studiu retrospectiv, unicentru, am dorit să reliefăm caracteristicile cheie ale primelor 100 de cazuri de COVID-19 spitalizate în clinica noastră după desemnarea acesteia drept unitate din linia întâi pentru spitalizarea acestora.

Datele evidenţiate în această lucrare vor putea ajuta la un management mai bun al pandemiei COVID-19. 


\section{BIBLIOGRAFIE}

1. World Health Organization. Statement on the second meeting of the International Health Regulations (2005) Emergency Committee regarding the outbreak of novel coronavirus (2019-nCoV) https:// www.who.int/news-room/detail/30-01-2020-statement-on-the-secondmeeting-of-the-international-health-regulations-(2005)-emergencycommittee-regarding-the-outbreak-of-novel-coronavirus-(2019-ncov).

2. World Health Organization. WHO characterizes COVID-19 as pandemic https://who.paho.org/hq/index.php?option=com_content\&vi ew=article\&id=1576\&ltemid=1926\&lang=en.

3. Carlos WG, Dela Cruz CS, Cao B, Pasnick S, Jamil S. Novel Wuhan (2019-nCoV) coronavirus. Am J Respir Crit Care Med. 2020; 201:p7-p8.

4. Chen N, Zhou M, Dong X, Qu J et al. Epidemiological and clinical characteristics of 99 cases of 2019 novel coronavirus pneumonia in Wuhan, China: A descriptive study Lancet. 2020; 395(10223):507-513.

5. INSP - Metodologia de supraveghere a sindromului respirator $\mathrm{cu}$ noul coronavirus - http://www.cnscbt.ro/index.php/metodologii/ infectia-2019-cu-ncov/1650-metodologia-de-supraveghere-a-covid19-actualizare-10-04-2020-1/file.

6. Laboratory diagnosis for novel coronavirus. WHO 2020 (https://www. who.int/healt-topics/coronavirus/laboratory-diagnostics-for-novelcoronavirus.

7. CDC: Dean AG, Arner TG, Sunki GG, Friedman R, Lantinga M, Sangam S, Zubieta JC, Sullivan KM, Brendel KA, Gao Z, Fontaine N,
Shu M, Fuller G, Smith DC, Nitschke DA, and Fagan RF. Epi Info TM, a database and statistics program for public health professionals. CDC, Atlanta, GA, USA, 2011.

8. Zhou P, Huang Z, Xiao Y, Huang X. Protecting Chinese Healthcare Workers while combating the 2019 novel coronavirus. Infect Control \& Hospital Epidemiology. 2020:1-4.

9. Al-Tawfig JA, Rodriguez-Morales AJ. Super-spreading events and contribution to transmission of MERS, SARS, and COVID-19. J Hosp Infect. 2020;S0195-6701(20)30177-8.

10. Kim Y, Ryu H, Lee S. Agent-based modeling for super-spreading events: A case study of MERS-Cov transmission dinamics in the Republic of Korea. Int J Environ Res Public Health. 2018;15(11).

11. Ran L, Chen X, Wang Y, Wu W, Zhang L, Tan X. Risk factors of healthcare workers with corona virus disease 2019: A retrospective cohort study in a dsignated hospital of Wuhan in China. Clin Infect Dis. 2020.

12. Wang W, Tang J, Wei F. Updated understanding of the outbreak of 2019 novel coronavirus (2019 nCoV) in Wuhan, China. J Med Virol. 2020;92:441-447.

13. Li Q, Guan X, Wu P, et al. Early Transmission Dynamics in Wuhan, China, of Novel Coronavirus-Infected Pneumonia. N Engl J Med. 2020;382(13):1199-1207.

Conflict of interest: none declared Financial support: none declared 